\title{
Comparative study on two different waste-water treatment plants in El-Menofeyia Province, Egypt
}

\author{
Mansour Galal*, E.A. Khallaf, A.H. Mohamed and N. Nabet \\ Zoo. Dept., Fac. of Sci., El-Menofeyia Univ., Egypt \\ *E-mail: mansour_galal_eg@yahoo.com
}

\begin{abstract}
This study was carried out at two different waste-water treatment plants in Quessna activated-sludge and Berkt El-Sabee trickling filters during a period extending between Dec. 2015 and Nov. 2016. Bacterial, protozoan and physico-chemical parameters were investigated monthly at these two plants to elucidate their performance efficiencies in treating and enhancing the waste-water. It was obviously that protozoa are represented by three main phyla (Sarcodina, Mastigophorea and Ciliophora) and the ciliated protozoa prevail the other two phyla. The diversity of the most common protozoan genera was more or less similar where Quessna WWTP has 25 genera (two sarcodines, four flagellates and 19 ciliates), while Berkt El-Sabee plant has 27 ones (three sarcodines, three flagellates and 21ciliated genera). On the other hand, the total protozoan numerical density was higher at Quessna as compared with that of Berkt El-Sabee (30247 organism/L and 25975/L, respectively). The total protozoa , Ciliophora and Mastiogophorea were proved to be significantly influenced to varying levels with Coliform bacteria and certain physico-chemical parameters. From the technological point of view, it was proved that the performing efficiency of the activatedsludge in Quessna WWTP is much better than that of Berkt El-Sabee. Accordingly, it could be possible to recommend the replacing of the trickling filters by the activated sludges to obtain more better wastewater treatment.
\end{abstract}

Key words : Activated sludge, bacteria, performance, protozoa and trickling filters.

\section{INTRODUCTION}

Aquatic ecosystem occupies about $70 \%$ of the globe and all the living organisms need water for their survival and growth (Patil et al., 2012 ; Reda, 2016). Accordingly, it is very crucial to check up water at regular intervals to avoid water borne diseases (Pauli et al., 2001 ; Simpi et al., 2011). Wastewater is a mixture of domestic, industrial, agricultural and rainwater. The development of wastewater treatment was driven by the need to recycle, retrieve and reduce the environmental contaminations brought about by the uncontrolled discharge of polluted effluents such as organic matter, nitrogenous, phosphorus compounds and pathogens into rivers and streams (Orrun et al., 2014). Biological wastewater treatment includes mainly two methods; trickling filters and the suspended growth reactors using the activated sludge (Curds and Hawk, 1975).

Protozoa are ubiquitous microorganisms, with small size, high reproduction rates, delicate external membranes and close contact with the surrounding environments. Hence protists may react more quickly to environmental change than most of other eukaryotic organisms and thus serve as bioindicators of water quality (Xu et al., 2009; Gomiero et al., 2013 ; Gong et al., 2005).

Protozooplankton is a key element in the food chain and according to Irigoien et al. (2005), protozoa can consume up to $100 \%$ of daily phytoplankton production. Moreover, they participate in the carbon cycle and are fundamental part of the microbial loop (Azam et al., 1983). This term derives from the fact that these organisms are situated in one trophic level, allowing them to transfer energy (carbon and other nutrients) acquired from lower trophic 


\section{Mansour Galal et al.}

levels, through the ingestion of organisms such as algae and bacteria, moving to higher trophic levels as they are ingested by other organisms (Xu et al., 2008; Polat and Koray, 2007 ; Medeiros, 2013). Protozoan grazing affect the abundance of bacteria in different aquatic ecosystems (Fried and Lemmer, 2003; Akpor et al., 2007).

The wastewater treatment systems can be characterized as an artificial ecosystem operating under severe conditions in which the key organisms are bacteria and protozoa (Papadimitriou et al., 2010). The presence of such bacterial populations allows the development of a microfauna consisting mainly of predator organisms such as protozoa and certain metazoan animals as rotifers, crustacean and insect larvae (Ginoris et al., 2007). It is generally accepted that protozoan grazing removes dispersed bacteria resulting in higher transparency (clarification) and lowering suspended organic loads in the output of the treated wastes (Pauli and Pauli, 2014).

Due to the variations in the feeding habits and phenotypic traits, different types of protozoa may have various functions in the wastewater treatment systems and exhibited different relations with environmental conditions (Martin-Cereceda et al., 1996 ; Hu et al., 2012). It was found that protozoan predation may exert pressure upon bacterial populations as they feed on pathogenic and fecal bacteria, thereby contributing to their removal efficiency at 95\% (Bitton; 2002 ; Tyagi et al.,2008).

\section{MATERIALS AND METHODS}

This study was carried out at two different wastewater treatment plants (WWTP); the activated sludges at Quessna and the trickling filters at Berkt El-Sabee. As the examined plants have different technology and various influent wastewater characters, different treatment efficiency was obtained. Monthly samples from these two plants were collected during the studying time. Water samples for Coliform bacteria were collected in $500 \mathrm{ml}$ sterilized glass bottles containing $1 \mathrm{ml}$ of $3 \%$ freshly prepared sodium thiosulphate in order to neutralize the residual chlorine and their numerical densities were detected by using the Most Probable Number (APHA, 1995). Another water sample was picked up using one liter glass bottle for both physico-chemical and zooplankton analysis. The collected water samples were transported as quickly as possible to our laboratories to be examined within six hours for the various bacterial populations and throughout 24 hours for rest of the parameters. Microscopical examination and identification of zooplankton with particular reference to protozoa was performed according to Patterson and Hedley (1996).

\section{RESULTS}

\section{The Physico-chemical values at Quessna and Berkt El-Sabee WWTPs:}

At Quessna water plant, the seasonal values of water temperature fluctuated from 17.8 ${ }^{\circ} \mathrm{C}$ in Winter to $28.9{ }^{\circ} \mathrm{C}$ in Summer. $\mathrm{P}^{\mathrm{H}}$ changed from 7.2 to 7.5 and from 7.2-7.7 in raw and treated water, respectively. The electrical conductivity in raw water stage varied between a minimum of $1181.7 \mu \mathrm{mhos} / \mathrm{cm}$ to a maximum of $1486.7 \mu \mathrm{mhos} / \mathrm{cm}$, while in treated water stage ranged between 1077.7 and $1132.7 \mu \mathrm{mhos} / \mathrm{cm}$. The COD content in raw water stage ranged between the minimum value of $122.3 \mathrm{mg} / \mathrm{L}$ and the maximum of $456.3 \mathrm{mg} / \mathrm{L}$, while in treated water stage ranged between 47.7 and $112 \mathrm{mg} / \mathrm{L}$. Simultaneously, BOD level in raw water ranged between a minimum of $73.4 \mathrm{mg} / \mathrm{L}$ and a maximum of $273.8 \mathrm{mg} / \mathrm{L}$, while in treated water its value oscillated between 17.2 and $67.2 \mathrm{mg} / \mathrm{L}$. The TSS content in raw water varied from $96.3 \mathrm{mg} / \mathrm{L}$ minimally to $168.8 \mathrm{mg} / \mathrm{L}$ maximally, while in treated water it moved from 37.7 to $66.7 \mathrm{mg} / \mathrm{L}$. The total nitrogen concentration in raw water achieved a minimum value of $33.7 \mathrm{mg} / \mathrm{L}$ and a maximum of $39.3 \mathrm{mg} / \mathrm{L}$, while in treated water its content ranged between 9.5 and $17 \mathrm{mg} / \mathrm{L}$. Alternatively, the total phosphate level in raw water changed 


\section{Comparative study on two different waste-water treatment plants in El-Menofeyia Province, Egypt}

between a minimum value of $5.8 \mathrm{mg} / \mathrm{L}$ and a maximum of $8.8 \mathrm{mg} / \mathrm{L}$, while in treated water its concentration ranged from 4.5 to $7.5 \mathrm{mg} / \mathrm{L}$ (Fig. 1). On the other hand, the seasonal values of the Physico-chemical parameters at Berkt El Sabee WWTP could be summarized as follows; water temperature fluctuated from $17.8{ }^{\circ} \mathrm{C}$ in Winter to $28.9{ }^{\circ} \mathrm{C}$ in Summer. $\mathrm{P}^{\mathrm{H}}$ changed from 7.1 to 7.6 and $7.4-8.0$ in raw and treated water respectively. The minimum electrical conductivity value of $1210.3 \mu \mathrm{mhos} / \mathrm{cm}$ belonging to raw water moved to its maximum value of $1540.3 \mu \mathrm{mhos} / \mathrm{cm}$, while in treated water it ranged between 1253 and $1355.7 \mu \mathrm{mhos} / \mathrm{cm}$. The COD value in raw water ranged between $174 \mathrm{mg} / \mathrm{L}$ minimally and $373 \mathrm{mg} / \mathrm{L}$ maximally, while in treated water it ranged between 138 to $268 \mathrm{mg} / \mathrm{L}$. The BOD content in raw water varied between a minimum of $176.9 \mathrm{mg} / \mathrm{L}$ and a maximum of 223.9 $\mathrm{mg} / \mathrm{L}$, while in treated water it oscillated between 71.1 and $160.8 \mathrm{mg} / \mathrm{L}$. The TSS content of raw water varied between $145 \mathrm{mg} / \mathrm{L}$ and $148 \mathrm{mg} / \mathrm{L}$, while in treated water its content ranged between 58.3 and $142.3 \mathrm{mg} / \mathrm{L}$. The Total Nitrogen level belonging to raw water changed between the minimum value of $43.4 \mathrm{mg} / \mathrm{L}$ and the maximum value of $53.4 \mathrm{mg} / \mathrm{L}$, while in treated water its level moved from 42.6 to $51.8 \mathrm{mg} / \mathrm{L}$. On the other hand, total Phosphate concentration in raw water achieved a minimum of $7.1 \mathrm{mg} / \mathrm{L}$ and a maximum of $9.4 \mathrm{mg} / \mathrm{L}$, while in treated water its value ranged between 6.0 and $8.4 \mathrm{mg} / \mathrm{L}$ (Fig. 2 ).

\section{Protozoan communities at Quessna and Berkt El-Sabee WWTPs:}

Water samples of the different locations belonging to these plants exhibited the presence of two major types of plankton. The most abundant group belongs to Kingdom Protista followed by some rotifers. Kingdom Protista was illustrated by three main protozoan phyla; Sarcodina, Mastigophora and Ciliophora. The latter prevails the other two phyla during different months of the present study at Quessna and Berkt El-Sabee wastewater treatment plants. Sarcodines are represented by two genera at the former plant and by three ones at the latter, mastigophores are illustrated by four and three genera at these two water plants respectively, while Ciliates are exhibited by 19 and 21 genera at the former and the latter plants respectively. These ciliates include three types; crawling, swimming and sessile organisms as could be seen in Table (1). Total cumulative numerical protozoan density at Quessna and Berkt El-Sabee WWTPs are $30247 \times 10^{3} / \mathrm{L}$ and $25975 \times 10^{3}$ organisms/L, respectively. The maximal numerical density of total protozoa, during the present investigation exhibited 10194 and $7575 \times 10^{3}$ organisms/L during Summer at Quessna and Berkt El Sabee respectively. The maximal numerical densities of the ciliated protozoan organisms were observed during Summer as well at Quessna stages; raw sewage, mixed liquor and treated water $\left(3680,4127\right.$ and $393 \times 10^{3}$ organisms/L respectively). Simultaneously, the maximal densities of ciliophoran organisms were detected during Summer also at Berkt El Sabee stages; raw sewage, trickling filter and treated water (3963, 1498 and $1111 \times 10^{3}$ organisms/L, respectively).

\section{The numerical densities of Bacteria at Quessna and Berkt El Sabee WWTPs:}

The highest numbers for total coliform belonging to raw sewage were observed on July and August $1.2 \times 10^{10}$ and $1.1 \times 10^{10} / 100 \mathrm{ml}$ respectively, While the lowest numbers were detected on September $\left(4.6 \times 10^{6} / 100 \mathrm{ml}\right)$. Regarding Fecal coliform and E. coli, it was found that bacterial numbers were $2.3 \times 10^{9}$ and $2.1 \times 10^{8} / 100 \mathrm{ml}$ on November respectively. On the other hand, treated water samples proved that total coliform varied from $2 \times 10^{3}$ to $5 \times 10^{9}$ on September and July respectively, While those of Fecal coliform were obtained on March and November $\left(4 \times 10^{3}\right.$ and $1 \times 10^{9} / 100 \mathrm{ml}$, respectively). Finally, $E$. 


\section{Mansour Galal et al.}

coli was obtained on April and August $\left(1.1 \times 10^{3}\right.$ and $1.5 \times 10^{7} / 100 \mathrm{ml}$, respectively). On the contrary, in raw sewage water samples at Berkt El-Sabee WWTP, the highest numbers for total coliform achieved $11 \times 10^{10}, 11 \times 10^{10}$ and $10 \times 10^{10} / 100 \mathrm{ml}$ during January, June and July respectively, While the lowest number was illustrated on March $\left(9 \times 10^{4} / 100 \mathrm{ml}\right)$. Fecal coliform and $E$. coli were observed maximally on January $1.5 \times 10^{10}$ and $0.93 \times 10^{10} / 100 \mathrm{ml}$, respectively. In treated water samples, total coliform ranged between $4 \times 10^{3}$ and $3.7 \times 10^{8}$ $/ 100 \mathrm{ml}$ on January and April respectively, While those of Fecal coliform were observed on March and October $\left(1 \times 10^{2}\right.$ and $1.1 \times 10^{8} / 100 \mathrm{ml}$, respectively). Finally, for $E$. coli, minimal and maximal densities were illustrated on March and June $\left(1 \times 10^{2}\right.$ and $3.7 \times 10^{8}$ $/ 100 \mathrm{ml}$, respectively).

It appears that the highest protozoan densities were obtained on May $\left(408010^{3} / \mathrm{L}\right)$ at Berkt El-Sabee, while those of Quessna water plant achieved their maximal numerical densities $\left(379010^{3} / \mathrm{L}\right)$ on July. The removal efficiency percentages of protozoa in the trickling filter at Berkt El-Sabee are higher than those at Quessna activated sludge from October to May, while the opposite behaviour was obtained during a period extending from June to September at the latter water plant. The highest removal percentages were obtained on July at Quessna (95.8\%) and on February at the other treatment plant (94.5\%) as could be seen in Table (2). Table (3) illustrated the major technological parameters (BOD, COD, TSS, Total nitrogen and Total phosphates) controlling the performance and the efficiency of the wastewater treatment plants. A comparison between the previously mentioned parameters at these two wastewater treatment plants could be observed in Figures 3 and 4. It was proved that efficiency of Quessna WWTP is better than that of Berkt El-Sabee.

\section{DISCUSSION}

Wastewater treatment is performed by two different methods; the first comprises the activation of the sludge where incorporated oxygen permits bacterial multiplication leading to oxidation of the polluted material, while the second involves trickling the used water over a deep bed of small pebbles. The rocky medium is colonized by bacteria which perform finally the breakdown of the pollutants.

Temperature is a vital parameter in the biological wastewater treatment processes. Sudden changes in temperature will affect the microbial activity which might influence processes like flocculation due to changed surface properties of the microbial cells (Manassra, 2006). Water temperature of the present study was nearly the same at all three collection points in both plants ( ranged between 17.8 and $30.5{ }^{\circ} \mathrm{C}$ ). However, Turbidity was higher during Summer than the other seasons which is parallel to data of Aull (2005) and it was positively correlated with BOD $(r=0.706, \mathrm{P}<0.05)$ and COD $(\mathrm{r}=0.728, \mathrm{P}<0.01)$. The present $p^{\mathrm{H}}$ values $(7.1-8.1)$ is lower on Summer as compared with those of other seasons like those of Birhanu (2007). The present data are concomitant with those of Elewa and Authman (1991) and Abd El-Satar (1994) during Winter. Present values have significant correlations with TDS of raw water at both plants $(\mathrm{r}=0.633, \mathrm{P}<0.05)$ and only of treated water at Quessna $(\mathrm{r}=0.643, \mathrm{P}<0.05)$ which agree with Patil et al, (2012) and Galal et al. (2014). Simultaneously, conductivity proved a significant correlation with temperature in raw water of both plants $(r=-0.794, p<0.01)$ exactly as that of NHDES (2008).

TDS and TSS are very important parameters influenced water quality where the former indicates all dissolved substances in water, while the latter is discharged due to the various industrial, agricultural and domestic human activities (Authman, 1998). Any sudden change in TDS could damage the aquatic life (Gaikwad; 2003 and Samrat et al., 2012). TDS achieved the maximal value in raw and treated water on Autumn and Summer respectively at Quessna WWTP, while at Berket El Sabee the maximal values obtained during Spring and 


\section{Comparative study on two different waste-water treatment plants in El-Menofeyia Province, Egypt}

Autumn at raw and treated water respectively. This agree with ELewa and Authman (1991). On the other hand, TSS of treated water at Quessna and Berket el Sabee were significantly correlated with oil and grease $(\mathrm{r}=0.846, \mathrm{p}<0.05)(\mathrm{r}=0.980, \mathrm{P}<0.01)$ respectively which is parallel to those of (EPA, 1975). BOD and COD are the most common parameters used to recognize the composition of wastewater (Russell, 2006; Abdalla and Hammam, 2014). The consistent positive relationship between the BOD and COD values throughout the study in both raw $(r=0.897, p<0.01)$ and treated water $(r=0.0924, p<0.05)(r=0.969, p<0.01)$ of Quessna and Beket el Sabee WWTPs indicates that the general balance of the composition of domestic and industrial sewage in the influent remained steady. It was found also that total phosphate were influenced by turbidity and TSS (Jones et al., 2011). This is parallel with the present data where there is a significant correlation between total phosphate and turbidity $(\mathrm{r}=$ $0.649, \mathrm{p}<0.05)$. Also, the present study showed a significant correlation between total phosphate and total nitrogen $(\mathrm{r}=-0.707, \mathrm{p}<0.01)$. It was proved that heavy metals levels are lower than the permissible limits apart from Cyanide which recorded 0.2 and $0.05 \mathrm{mg} / \mathrm{L}$ in raw water of Quessna and Berket el Sabee WWTPs on Autumn respectively. This could be interpreted as a result of the various industrial activities in the surrounding location.

The present maximal numerical density of total protozoa exhibited 10194 and 7575 organism $\times 10^{3} / \mathrm{L}$ during Summer at Quessna and Berkt El Sabee respectively. However, the maximal numerical densities of ciliates were obtained during Summer at Quessna stages; raw sewage, mixed liquor and treated water $\left(3680,4127\right.$ and 393 organism $\times 10^{3} / \mathrm{L}$ respectively) and Berkt El-Sabee stages; raw sewage, trickling filter and treated water (3963, 1498 and 1111 organisms $x 10^{3} / \mathrm{L}$ respectively). Protozoa associated with sewage treatment have been considered by different workers as mentioned by Laybourn (1984), but the most comprehensive study of protozoa and their role in sewage treatment processes has been carried out by Curds and Cockburn (1970 a) who proved that ciliates were the dominant group, followed by Rhizopoda and Phytomastigophorea where 67 species of ciliates were detected in activated sludges, where those of percolating filters achieved 53 ciliophoran species only. Also, Curds (1975) proved the presence of a succession of species through the depth. It is worthy to mention that the abundance of protozoa in the present study are in the same order; Ciliates (19 and 21 genera), phytomastigophoreans (4 and 3) followed by Sarcodines (2 and 3) at Quessna and Berkt El-Sabee WWTPs respectively.

It was proved that there is a correlation between the composition of the protozoan community in a wastewater treatment plant and the quality of the produced effluent (Curds and Cockburn; $1970 \mathrm{a} \& \mathrm{~b}$ ). They found also that the effluent of high quality is characterized by low BOD values, low suspended solids, a wide variety and high numerical densities of ciliated protozoan organisms. After a few days of wastewater treatment BOD declined from $53-70 \mathrm{mg} / \mathrm{L}$ to $7-24 \mathrm{mg} / \mathrm{L}$ and the suspended solids dropped from $86-118 \mathrm{mg} / \mathrm{L}$ to $26-34$ $\mathrm{mg} / \mathrm{L}$. The improved BOD and TSS could be referred to a decline in the viable bacterial numbers from $106-16010^{6} / \mathrm{ml}$ to $1-910^{6} / \mathrm{ml}$ (Curds et al., 1968). On the other hand, data of the present study indicated that the BOD of the effluent treated water varied between 17.2 minimally and $67.2 \mathrm{mg} / \mathrm{l}$ maximally, those of TSS decreased to 37.7 and $66.7 \mathrm{mg} / \mathrm{l}$, those of total nitrogen oscillates between 9.5 and $17.0 \mathrm{mg} / \mathrm{l}$, while those of total phosphates ranged from 4.5 to $7.5 \mathrm{mg} / \mathrm{l}$.

Protozoan populations of the two plants of the present study show poor diversity which might be attributed mainly to the added primary chlorine at the beginning of water treatment where diversity of various organisms in water treatment plants depending on the influent composition as well as the operational parameters of the wastewater treatment unit (Papadimitriou et al., 2004). In the present study, Protozoa persisted all over the year and 


\section{Mansour Galal et al.}

hence they contributed the highest percentage of the total numerical density of the examined zooplankton recorded in water samples. The highest occurrence frequencies of the dominant protozoan genera are Vorticella, Cyclidium and Arcella at Quessna plant, while those at Berket El Sabee are Vorticella, Aspidisca, Arcella and Dinoflagellate.

In the present study, total and fecal coliform beside $E$. coli were detected in raw wastewater samples from both sewage treatment plants. Since wastewater from homes, hospitals and commercial buildings were collected in sewers and flow to sewage treatment plants, high fecal bacterial counts were expected in the raw sewage (Samie et al., 2009; Hendricks and Pool, 2012). Concerning the final effluent the maximal densities of total and fecal coliform with E.coli at Quessna WWTP were $5 \times 10^{9}, 1 \times 10^{9}$ and $1.5 \times 10^{7}$ respectively and the minimum were $2 \times 10^{3}, 4 \times 10^{3}$ and $1.1 \times 10^{3}$. In Berket El Sabee treated water samples the maximum level of total, fecal coliform and E.coli were $3.7 \times 10^{8}, 1.1 \times 10^{8}$ and $3.7 \times 10^{7} / 1$ respectively and the minimum were $4 \times 10^{3}, 1 \times 10^{2}$ and $1 \times 10^{2} / 1$. The final numerical densities of coliforms could reach very high values, which could be harmful for the public health if these waters will be discharged at the environment in inadequate sites. So it is recommended Prior treatment, wastewater that is passed to a trickling filter must be pretreated firstly to remove solid and greasy materials, so as to prevent them from covering the thin layer of microorganisms present and to prevent the solid and greasy materials from killing them (Akpor et al., 2014).

Finally, it is necessary to mention that analyzing the major technological parameters proved that the efficiency of the wastewater treatment plant at Quessna is much better than that of Berkt El-Sabee plant and consequently, the latter plants should be replaced by the former type of treatment.

Table (1)-: Protozoan Genera and their prevalence at Quessna AND Berkt El-Sabee Wastewater Treatment Plants.

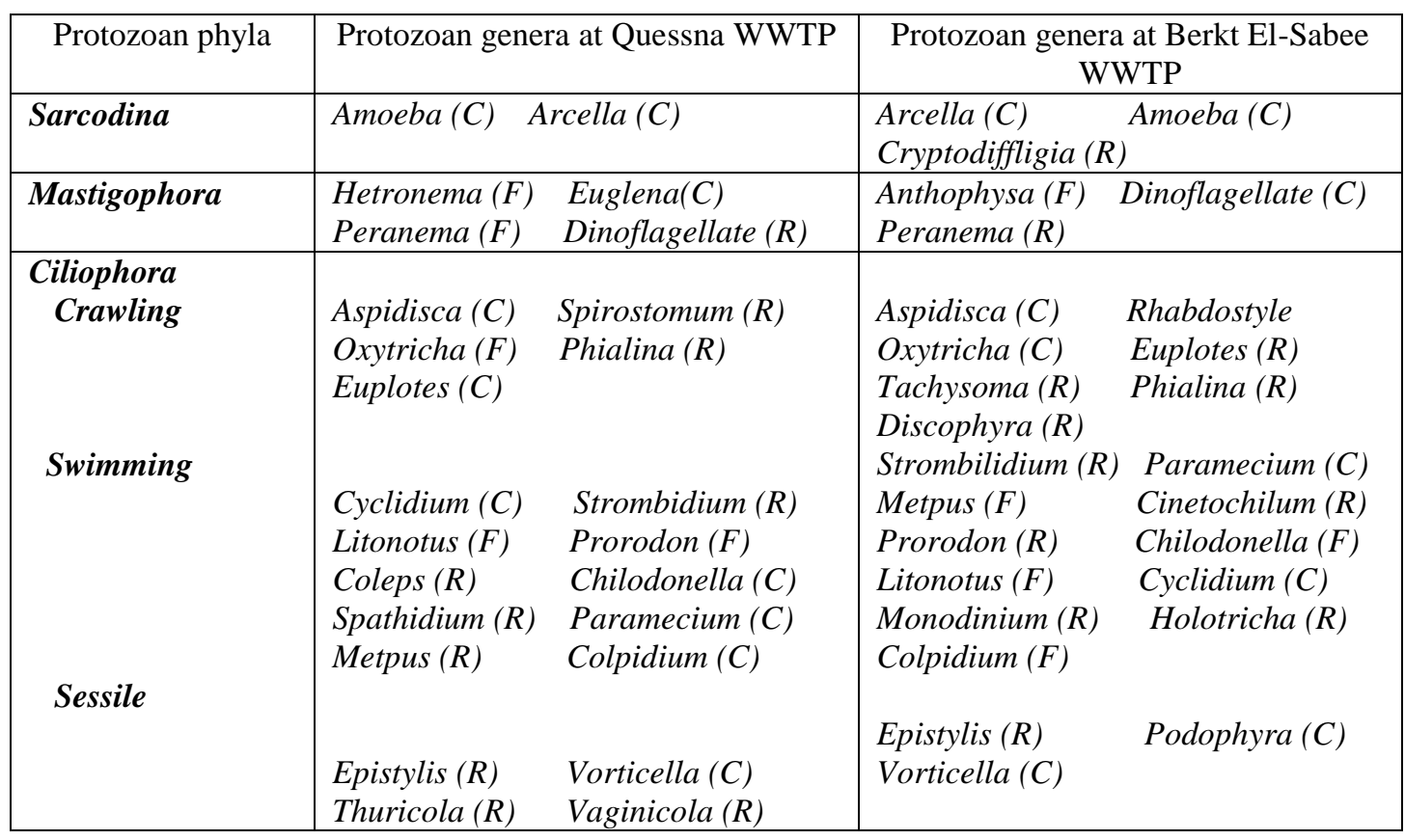

$\mathrm{C}=$

Com mon genera $\mathrm{F}=$ Frequ ent genera $\mathrm{R}=$ Rare genera

Table (2): Mont hly efflue 
Comparative study on two different waste-water treatment plants in El-Menofeyia Province, Egypt

nt and influent total protozoa beside their remaining percentages at Berkt ElSabee and Quessna WWTPs in El-Menofeyia Province, Egypt.

\begin{tabular}{|l|l|l|l|l|}
\hline Month & Total influ. Proz. & Total effl. Proz. & Total infl. Proz. & Total effl. Proz. \\
\hline Dec 2015 & 1789 & $134(7.4 \%)$ & 1790 & $592(33.1 \%)$ \\
\hline Jan 2016 & 2528 & $255(10.1 \%)$ & 2280 & $285(12.5 \%)$ \\
\hline Feb & 2229 & $123(5.5 \%)$ & 2876 & $486(16.9 \%)$ \\
\hline Mar & 1345 & $265(19.7 \%)$ & 3336 & $591(17.7 \%)$ \\
\hline April & 1716 & $201(11.7 \%)$ & 2126 & $408(19.2 \%)$ \\
\hline May & 4080 & $280(6.9 \%)$ & 3355 & $750(22.4 \%)$ \\
\hline June & 2220 & $355(16.0 \%)$ & 3062 & $305(10.0 \%)$ \\
\hline July & 2415 & $570(23.6 \%)$ & 3790 & $160(4.2 \%)$ \\
\hline Aug & 2940 & $405(13.8 \%)$ & 3342 & $285(8.5 \%)$ \\
\hline Sept & 2220 & $1170(52.7 \%)$ & 1635 & $690(42.2 \%)$ \\
\hline Oct & 1367 & $104(7.6 \%)$ & 1291 & $366(28.4 \%)$ \\
\hline Nov & 1126 & $126(11.2 \%)$ & 1364 & $455(33.4 \%)$ \\
\hline
\end{tabular}

Table (3) : Technological parameters and wastewater characteristics at the two examined wastewater treatment plants

\begin{tabular}{|c|c|c|c|c|c|c|c|}
\hline \multirow{2}{*}{$\begin{array}{l}\text { Season } \\
\text { Winter }\end{array}$} & \multirow[b]{2}{*}{ Parameters } & \multicolumn{3}{|c|}{ Berkt El-Sabee } & \multicolumn{3}{|l|}{ Quessna } \\
\hline & & Influent & Effluent & Efficiency & Influent & Effluent & Efficiency \\
\hline Winter & $\begin{array}{lc}\text { COD } & \mathrm{mg} / \mathrm{l} \\
\text { BOD } & \mathrm{mg} / \mathrm{l} \\
\text { TSS } & \mathrm{mg} / \mathrm{l} \\
\text { Total-N } & \mathrm{mg} / \mathrm{l} \\
\text { Total-P } & \mathrm{mg} / \mathrm{l}\end{array}$ & $\begin{array}{l}122.33 \\
73.40 \\
96.33 \\
38.17 \\
7.62\end{array}$ & $\begin{array}{l}56.00 \\
28.60 \\
37.67 \\
13.20 \\
7.46\end{array}$ & $\begin{array}{l}54.22 \% \\
61.04 \% \\
60.90 \% \\
65.41 \% \\
2.10 \%\end{array}$ & $\begin{array}{l}362.3 \\
217.4 \\
145.7 \\
53.2 \\
9.4\end{array}$ & $\begin{array}{l}187.7 \\
112.6 \\
58.3 \\
42.6 \\
8.2\end{array}$ & $\begin{array}{l}48.21 \% \\
48.21 \% \\
59.95 \\
19.86 \\
12.77\end{array}$ \\
\hline Spring & $\begin{array}{lc}\text { COD } & \mathrm{mg} / \mathrm{l} \\
\text { BOD } & \mathrm{mg} / \mathrm{l} \\
\text { TSS } & \mathrm{mg} / \mathrm{l} \\
\text { Total-N } & \mathrm{mg} / \mathrm{l} \\
\text { Total-P } & \mathrm{mg} / \mathrm{l}\end{array}$ & $\begin{array}{l}456.33 \\
273.80 \\
106.33 \\
39.27 \\
7.61\end{array}$ & $\begin{array}{l}67.67 \\
40.60 \\
45.33 \\
10.77 \\
4.93\end{array}$ & $\begin{array}{l}85.17 \% \\
85.17 \\
57.37 \\
72.58 \\
35.25\end{array}$ & $\begin{array}{l}311.7 \\
187.0 \\
148.0 \\
53.4 \\
8.1\end{array}$ & $\begin{array}{l}138.0 \\
82.8 \\
78.0 \\
51.8 \\
6.9\end{array}$ & $\begin{array}{l}55.72 \% \\
55.72 \% \\
47.30 \% \\
3.00 \% \\
15.76 \%\end{array}$ \\
\hline Summer & $\begin{array}{lc}\text { COD } & \mathrm{mg} / \mathrm{l} \\
\text { BOD } & \mathrm{mg} / \mathrm{l} \\
\text { TSS } & \mathrm{mg} / \mathrm{l} \\
\text { Total-N } & \mathrm{mg} / \mathrm{l} \\
\text { Total-P } & \mathrm{mg} / \mathrm{l}\end{array}$ & $\begin{array}{l}269.00 \\
161.40 \\
136.00 \\
33.73 \\
8.79\end{array}$ & $\begin{array}{l}112.00 \\
67.20 \\
53.33 \\
9.50 \\
5.98\end{array}$ & $\begin{array}{l}58.36 \\
58.36 \\
60.78 \\
71.84 \% \\
32.03\end{array}$ & $\begin{array}{l}373.0 \\
223.9 \\
146.7 \\
48.2 \\
7.1\end{array}$ & $\begin{array}{l}268.0 \\
160.8 \\
95.3 \\
44.9 \\
6.0\end{array}$ & $\begin{array}{l}28.15 \% \\
28.17 \% \\
35.00 \% \\
6.92 \% \\
15.27 \%\end{array}$ \\
\hline Autumn & $\begin{array}{lc}\text { COD } & \mathrm{mg} / \mathrm{l} \\
\text { BOD } & \mathrm{mg} / \mathrm{l} \\
\text { TSS } & \mathrm{mg} / \mathrm{l} \\
\text { Total-N } & \mathrm{mg} / \mathrm{l} \\
\text { Total-P } & \mathrm{mg} / \mathrm{l}\end{array}$ & $\begin{array}{l}158.00 \\
171.67 \\
168.00 \\
30.60 \\
5.78\end{array}$ & $\begin{array}{l}47.67 \\
17.20 \\
66.67 \\
17.03 \\
4.51\end{array}$ & $\begin{array}{l}69.83 \\
89.98 \\
60.32 \\
44.34 \\
21.91\end{array}$ & $\begin{array}{l}174.0 \\
176.9 \\
145.0 \\
43.4 \\
8.7\end{array}$ & $\begin{array}{l}145.0 \\
71.1 \\
142.3 \\
43.1 \\
8.4\end{array}$ & $\begin{array}{l}16.67 \% \\
59.82 \% \\
1.48 \% \\
0.70 \% \\
2.66 \%\end{array}$ \\
\hline
\end{tabular}


Mansour Galal et al.

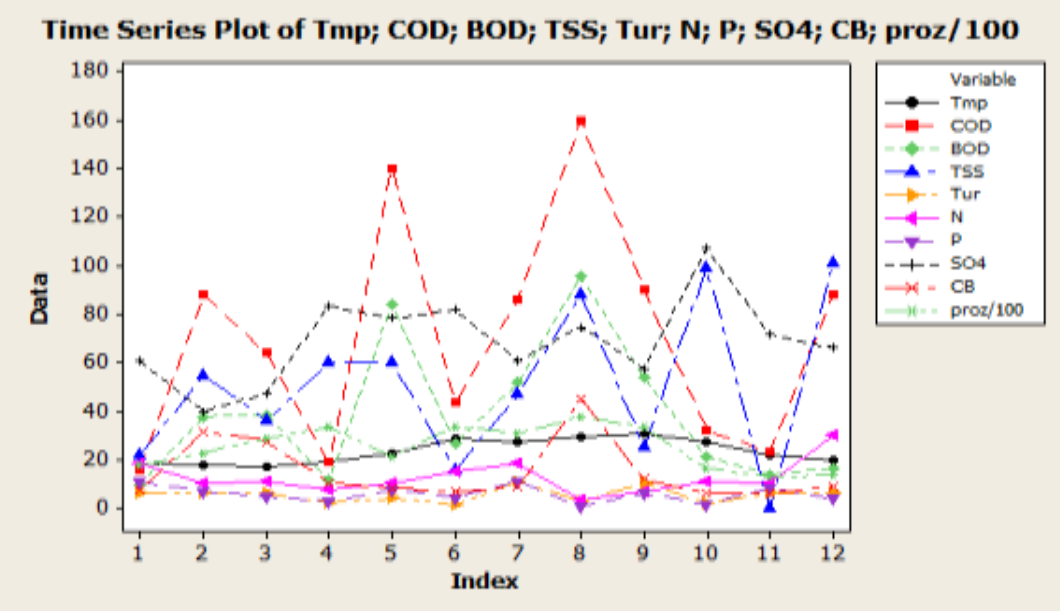

Fig. (1). Main biotic and abiotic parameters at Quessna WWTP in El-Menofeyia Province, Egypt.

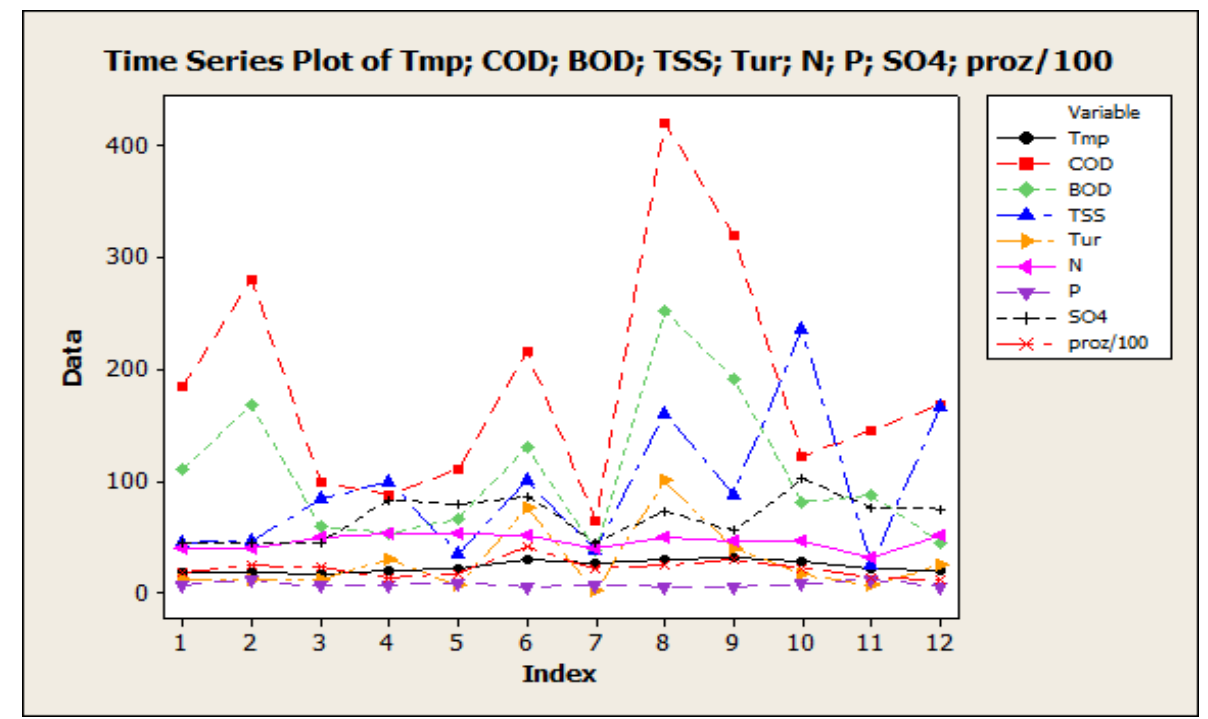

Fig. (2). Main biotic and abiotic parameters at Berkt El-Sabee WWTP in El-Menofeyia Province, Egypt. 


\section{Comparative study on two different waste-water treatment plants in El-Menofeyia Province, Egypt}

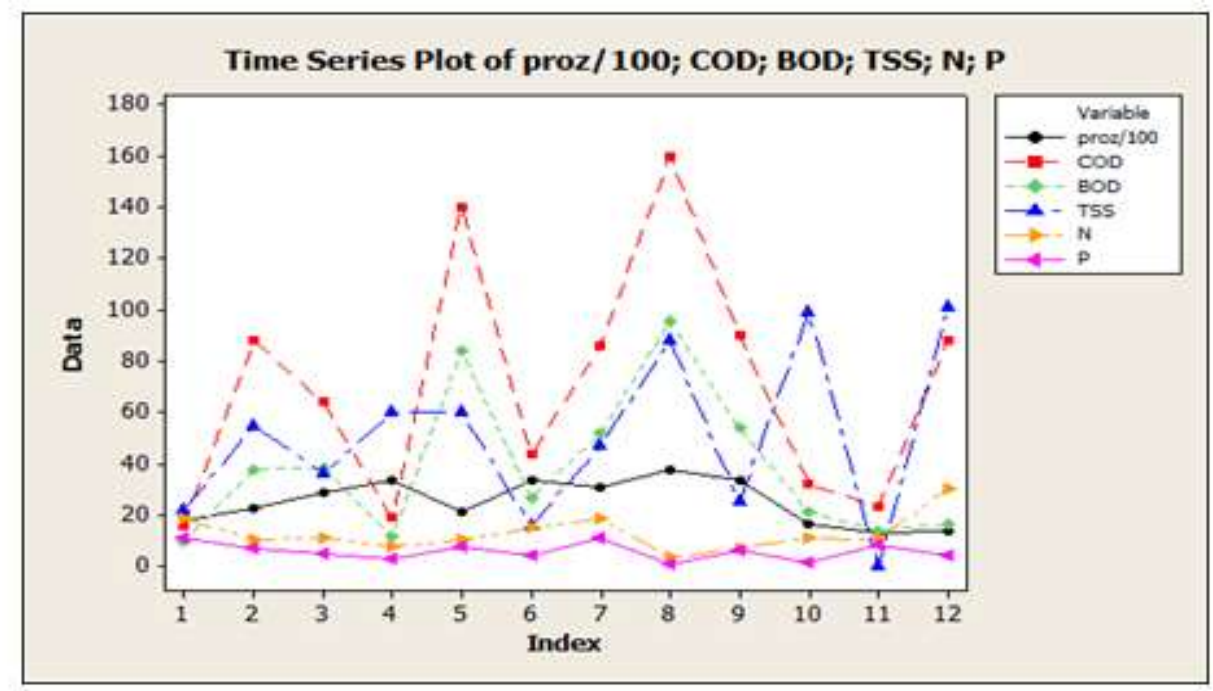

Fig. (3). Technological parameters at Quessna WWTP in El-Menofeyia Province, Egypt.

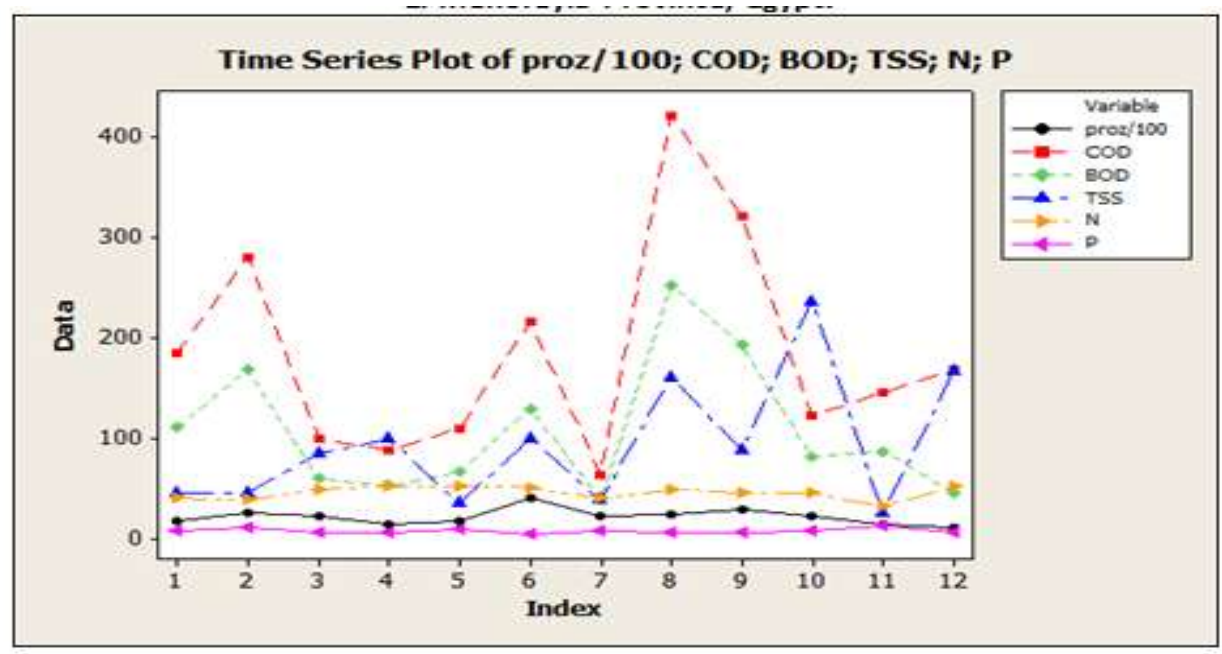

Fig. Fig. (4). Technological parameters at Berkt El-Sabee WWTP in El-Menofeyia Province, Egypt.

\section{REFERENCES}

Abdalla, K. and Hammam, G. (2014). Correlation between biochemical oxygen demand and chemical oxygen demand for various wastewater treatment plants in Egypt to obtain the biodegradability indices. Inter. J. Sci.: Basic and Applied Res., 13(1): 42-48.

Abd-El Satar, A.M. (1994). Studies on some environmental factors affecting the distribution of some chemical elements and productivity of river Nile at El kanater El Khairia. MSc. Thesis Fac., Sci., Cairo University, Egypt.

Akpor O.B., Momba M.N.B. and Okonkwo J. (2007). Phosphorus and nitrate removal by selected wastewater protozoa isolates. Pakistan J. Biolog. Sci., 10 (22): 4008-4014. 


\section{Mansour Galal et al.}

Akpor, O.B.; Ogundeji, M.D., Olaolu, T.D. and Aderiye, B.I. (2014). Microbial roles and dynamics in wastewater treatment systems: An Overview. Inter. J. Pure \& Appl. Biosci., 2 (1): 156-168.

American Public Health Association (APHA) (1995). Standard methods. $19^{\text {th }}$ ed, American Public Health Association, Washington, D.C.

Aull, M.E. (2005). Water Quality Indicators in Watershed Subbasins with Multipile Land Uses (Doctoral dissertation, Worcester Polytechnic Institute).

Authman, M. (1991). Studies on some biological aspects of Bagrus bayad (Family: Bagridae) from Bahr Shebin Canal. MSc. Thesis, Zool., Dep., Fac., Sci., Menoufiya University, Egypt.

Authman, M. (1998). A study on fresh water Pollution and its effects on zooplankton and fish Oreochromis niloticus in Shanwan Drainage Canal at Almay, Al Menoufeya Province, Egypt. PhD. Thesis, Zool., Depart., Fac., Sci., Menoufiya University, Egypt.

Azam, F.; Fenchel, T.; Field, J. G.; Gray, J. S.; Meyer-reil, L. A.; Thingstad, F. (1983). The ecological role of water-column microbes in the sea. Marine Ecology Progress Series, $10,257-263$.

Birhanu, M. (2007). Assessment of Physico-chemical and microbiological quality of drinking water at sources and house hold in selected communities of Akaki-kaliti sub city, Addis Ababa City Administration. M.Sc., Addis Ababa University, School of Graduate Studies.

Bitton, G. (2002).Encyclopedia of Environmental Microbiology. Willey International Publication, 4, 2605-2612.

Curds C.R. and Cockburn A. (1970 a). Protozoa in biological sewage treatment processes: A survey of the protozoan fauna of British fauna percolating filters and activated sludge plants. Water Reserve, 4: 225-236

Curds, C. R. and Cockburn, A. $(1970$ b). Protozoa in biological sewage-treatment processes-II. Protozoa as indicators in the activated-sludge process. Water Res., 4(3): 237-249.

Curds, C.R and Hawk, H.A (1975). Ecological aspects of used-water treatment. Academic Press, London.

Curds, C.R (1973).The role of Protozoa in the activated-sludge process. Amer. Zoologist, 13: 161-169.

Curds, C.R.; Cockburn, A. and Vandyke, J.M. (1968). An experimental study of the role of ciliated Protozoa in the activated-sludge process. Water Pollut. Control, 67: 312-329

Elewa, A. A. and Mahdi, H. (1988). Some limnological studies on the nile water at Cairo, Egypt. Bull . Inst. Oceanogr, Fish., A.R.E., 14:141-152.

Elewa, A. and Authman, M. (1991). Limnological studies on Bahr Shebeen El Kom Canal, Minofeya Governorate, Egypt. Fac., Sci., Zagazig University, Egypt.

EPA, Environmental Protection Agency (1975). Treatability of oil and grease discharged to publicity owned treats works. U.S. 20460.

Fried, J. and Lemmer, H. (2003). Dynamics and function of ciliates in sequencing batch biofilm reactor. Water Sci. Technol., 47(5): 189-196.

Gaikwad, L.B. (2003). Hydrobiological study of Nandrabad dam. Ph. D. thesis. Dr. Babasaheb Ambedkar Marathwada University, Aurangabad.

Galal, M.; Khallaf, E.; Elsabbagh, S. and Nabet, N. (2014). A Study of the Physicochemical and Biological Characteristics of Raw Water, Filtrated and Treated Water at a Water Treatment Plant in Shebin El Kom, Menoufiya, Egypt. J. Egypt.Acad.Soc.Envir.Dev., 15: 160-170. 


\section{Comparative study on two different waste-water treatment plants in El-Menofeyia Province, Egypt}

Ginoris, Y. P., Amaral, A. L., Nicolau, A., Coelho, M. A. Z., \& Ferreira, E. C. (2007). Raw data pre-processing in the protozoa and metazoa identification by image analysis and multivariate statistical techniques. J. Chemometrics, 21(3-4): 156-164.

Gomiero A.; Dagnino A.; Nasci C. and Viarengo A. (2013). The use of protozoa in ecotoxicology: Application of multiple endpoint tests of the ciliate E. crassus for the valuation of sediment quality in coastal marine ecosystems. Sci. Total Environ., 442: 534-544.

Gong J.; Song W. and Warren A. (2005). Periphytic ciliate colonization: annual cycle and responses to environmental conditions. Aquat. Microb. Ecol., 39: 159-170

Hendricks, R. and Pool, E.J. (2012). The effectiveness of sewage treatment processes to remove faecal pathogens and antibiotic residues. J. Environ. Sci. Health, Part A, 47(2): 289-297.

Hu, B.; Qi, R.; An W. and Yang, M. (2012). Responses of protists with different feeding habits to the changes of activated sludge conditions: a study based on biomass data. J. Environ. Sci., 24(12): 2127-2132.

Irigoien, X.; Flyn, K. J. and Harris, R. P. (2005). Phytoplankton blooms: a 'loophole' in microzooplankton grazing impact. J. Plankton Res., Oxford, 27:313-321.

Jones, A.S.; Stevens, D.K.; Horsburgh, J.S. and Mesner, N.O. (2011). Surrogate measures for providing high frequency estimates of total suspended solids and total phosphorus concentrations. JAWRA J. Amer. Water Resources Assoc., 47(2): 239-253.

Laybourn, J. (1984). A functional biology of free-living Protozoa .Croom Helm London and Sydney.

Manassra, R.I. (2006). Study of temperature effects on activated sludge floc stability. MSc. Thesis, Applied Environmental Measurement Techniques, Civil and Environmental Engineering Water Environment. Technology, Chalmers University of Technology, Göteborg, Sweden.

Martin-Cereceda, M.; Serrano, S. and Guinea, A. (1996). A comparative study of ciliated protozoa communities in activated-sludge plants. FEMS Microbiol. Ecol., 21(4): 267276.

Medeiros, M.L.Q.; Araújo, M.F.F.; Sodré-Neto, L. and Amorim, A.S. (2013). Spatial and temporal distribution of free-living protozoa in aquatic environments of a Brazilian semi-arid region. Ambi-Agua, Taubaté, 8(2): 46-56.

New Hampshire Department of Environmental Services (NHDES) (2008). Interpreting VRAP Water Quality Monitoring Parameters. http://des.nh.gov/organization/divisions/water/wmb/vrap/index.htm.

Orrun, M.; Garaizabal, I.; Bravo, Z.; Parada, C.; Barcina, I. and Arana, I. (2014). Mechanisms involved in Escherichia coli and Serratia marcescens removal during activated sludge wastewater treatment. Microbiol. Open, 3(5): 657-667.

Papadimitriou, C.A.; Papatheodoulou, A.; Takavakoglou, V.; Zdragas, A.; Samaras, P., Sakellaropoulos, G. P. and Zalidis, G. (2010). Investigation of protozoa as indicators of wastewater treatment efficiency in constructed wetlands. Desalination, 250(1): 378-382.

Patil, P.N.; Sawant, D.V. and Deshmukh, R.N (2012). Physico-chemical parameters for testing of water- A review. Inter. J. Environ. Sci., 3(3): 1194-1207.

Patterson. D.J. and Hedley, S. (1996). Free-living freshwater protozoa. A color guide. Wolfe Publishing Ltd., England. 


\section{Mansour Galal et al.}

Pauli W.; Jax, K. and Berger S. (2001). Protozoa in Wastewater Treatment: Function and importance in: The Handbook of Environmental Chemistry Vol. 2 Part K Biodegradation and Persistence (ed. by B. Beek) Springer-Verlag Berlin Heidelberg.

Polat, S. and Koray, T. (2007). Planktonic dinoflagellates of the northern Levantine Basin, northeastern Mediterranean Sea. European J. Protistol., 43(3):193-204.

Reda A.H. (2016). Physico-chemical analysis of drinking water quality of Arbaminch Town. J. Environ. Anal. Toxicol., 6(2): 1-5.

Russell, D.L. (2006). Practical Wastewater Treatment. John Wiley \& Sons, Inc., Hoboken, NJ, USA.

Samie, A.; Obi, C.; Igumbor, J. and Momba, M. (2009). Focus on 14 sewage treatment plants in the Mpumalanga Province, South Africa in order to gauge the efficiency of wastewater treatment. Afr. J. Biotech., 8(14): 3276-3285.

Samie, A., Obi, C., Igumbor, J., Momba, M. (2009). Focus on 14 sewage treatment plants in the Mpumalanga Province, South Africa in order to gauge the efficiency of wastewater treatment. Afr. J. Biotech., 8(14), 3276-3285

Samrat, A.D.; Wanjule, R.V.; Shinde, S. and Pande. B.N. (2012). Study of the Physicochemical parameters of Harsul Dam, Aurangabad. Proc. Inter. Conference SWRDM, Department of Environmental Science, Shivaji University, Kolhapur, 208-213.

Simpi, B.; Hiremath, S. M.; Murthy, K. S; Chandrashekarappa, K. N.; Patel, A.N. and Puttiah, E.T. (2011). Analysis of Water Quality Using Physico-Chemical Parameters Hosahalli Tank in Shimoga District, Karnataka, India. Global J. Sci. Frontier Res., 1(3): 31-34.

Tyagi, V.K.; Subramaniyan, S.; Kazmi, A.A. and Chopra, A.K.(2008). Microbial community in conventional and extended aeration activated sludge plants in India. Ecological Indicators, 8(5): 550-554.

Xu, H., Min, G. S., Choi, J. K., Jung, J. H., \& Park, M. H. (2009). An approach to analyses of periphytic ciliate colonization for monitoring water quality using a modified artificial substrate in Korean coastal waters. Mar. Pollut. Bull., 58(9): 1278-1285.

$\mathrm{Xu}, \mathrm{H}$.; Song, W.; Warren, A.; Al-Rasheid, K.A.; Al-Farraj, S.A.; Gong, J. and Hu, X. (2008). Planktonic protist communities in a semi-enclosed mariculture pond: structural variation and correlation with environmental conditions. J. Mar. Biol. Assoc. U. K., 88(7): 1353-1362. 


\section{Comparative study on two different waste-water treatment plants in} El-Menofeyia Province, Egypt

$$
\begin{aligned}
& \text { دراسات مقارنة على محطتين مختلفتين لمعالجة مياه الصرف في محافظة المنوفية بمصر } \\
& \text { منصور جلال, السيد خلاف, عزة محمد، نورا نابت الني } \\
& \text { قسم علم الحيوان - كلية العلوم - جامعة المنوفيـة فئلة }
\end{aligned}
$$

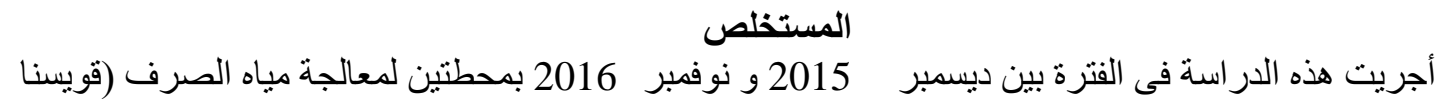

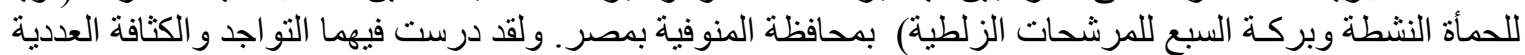

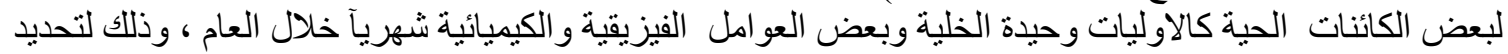

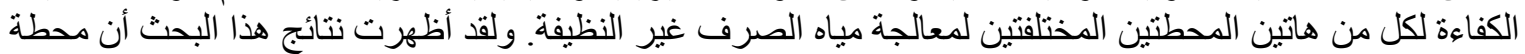

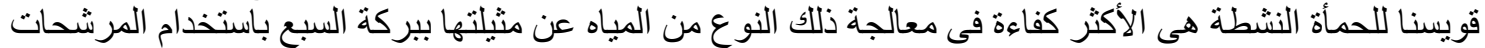
الزلطية. ولئللك يمكن التوصية بإحلال المرشحات الزلطية بمحطات الحمأة النشطة للحصول على جودة أعلى لمياه الصرف الصفاه 